\title{
Effect of Inquiry Techniques on the Interest of Technical College Students in Auto Mechanic in Nigeria
}

\author{
Ogundola Ilesanmi Peter (Ph.D) \\ Department Of Curriculum Studies, Faculty Of Education, Ekiti State University, Ado-Ekiti, Nigeria
}

\begin{abstract}
The effect of guided and structured inquiry techniques on the interest of technical college students in vocational education auto mechanics is the main concern of the study. The research adopted a quasiexperimental research design, precisely, pre-test, post-test non equivalent group design which involved groups of students in their intact classes. The population for the study was 195 year II Auto Mechanic (AM) students in the technical colleges in Ekiti State. Two research questions and three null hypotheses tested at 0.05 level of significance guided the study. The instruments used for data collection was the Auto Mechanic Interest Inventory (AMII). The AMII, training manual, Guided and Structured inquiry lesson plans were all subjected to face and content validation by three experts. The trial test for determining the coefficient of internal consistency of the AMII items was carried out using Cronbach Alpha. The reliability coefficient computed for the AMII was 0.85. Mean was used to answer the research questions, while ANCOVA was employed to test the hypotheses. The study revealed that both guided and structured inquiries stimulate students' interest but that the guided inquiry instructional technique was more effective in stimulating students' interest than the structured inquiry technique in auto mechanic. The study also revealed that there was effect of gender on students' interest in auto mechanic favouring boys. There were no interaction effects of treatments and gender on interest of technical college students in auto mechanic. Thus the effectiveness of guided inquiry instructional technique on students' interest in auto mechanic was independent of gender. It was thereafter recommended that Ministries of Education, National Business and Technical Examination Board (NABTEB) and NBTE should organize workshops, seminars and conferences for technical teachers on regular basis to enlighten and improve their knowledge and skills on the use of the guided inquiry instructional techniques among other recommendations. This is with a view to stimulate student's interest and thus encourage recruits
\end{abstract}

Key words: interest, Technical College, students, automobiles, auto mechanic, guided inquiry, structured inquiry.

\section{Introduction}

Interest is a persisting tendency to pay attention and enjoy some activities. It is viewed as emotionally oriented behavioural trait which determines trade students' enthusiasm in tackling educational programmes or other activities (Chukwu, 2002). Osuafor (2001) described interest as that attraction which forces or compels a student to respond to a particular stimulus. To some others, it is a phenomenon that emerges from an individual's interaction with the environment (Hidi \& Renninger, 2006; Silvia, 2006). This postulate is also the starting point of an educational theory of interest (Prenzel,1992; Schiefele, Krapp, Prenzel, Heiland, \& Kasten, 1983), also called 'person-object theory of interest' (Krapp, 2002,). According to this theory, interests evolve out of manifold relationships between persons and objects in social and institutional settings.

An interest represents a specific and distinguished relationship between a person and an object. Thus, such object can be concrete, topical, subject-matter or abstract ideas, i.e. a certain part of the cognitively represented environment. Again, such interest may also be for short or long periods of time. Research in education can assist to better understand how interest in vocational education in general and auto mechanic in particular is developed, how it expands, disappears and how it can be sustained and promoted. One important role of the teacher is to order and structure the learning environment and use of motivational techniques to secure and sustain the attention and interest of the learners (Moore, 1998). Interest does not come as a result of force, it is as a result of an individual's eagerness to learn. Therefore, interest is an affective behaviour that can be aroused and sustained in teaching and learning through appropriate teaching strategy. Students' interest and achievement in any learning activity is sustained by the active involvement of the learner in all aspects of the learning process. Ogwo and Oranu (2006) and Ngwoke (2004) emphasized that unless the teacher stimulates students' interest in learning, students' achievement will be minimal. Hence, it is essential that technical/vocational education teachers use teaching methods such as inquiry teaching technique which ensures students' active involvement in learning, stimulate and arouse interest and at the same time improve performance in a chosen trade of study.

Inquiry-based teaching is one of the most effective methods of active learner participation in learning process. According to Agboola and Oloyede (2007), it creates situations in which students take the role of 
scientists. This is because students take the initiative to observe and question phenomena, pose explanations of what they see, devise and conduct tests to support or contradict their theories, analyse data, draw conclusion from experimental data, design and build models or any combination of these. Eick and Reed (2002) asserted that the inquiry teaching method is a project-oriented pedagogic strategy based on social-constructivist theory of learning. It is a method that elicits critical thinking skills. That is, mentally engaging in cognitive process to understand conflicting factors in a situation (Moon, 1999; Davis 1996). Thus, inquiry helps students to develop higher order thinking skills by prompting students to relate new knowledge to their previous knowledge; to think in both abstract and concrete terms, apply specific strategies to novel tasks and understand their own thinking strategies (Hmelo and Ferrari, 1997). In inquiry situation, students learn not only concepts and principles but self-direction, responsibility and social communication.

The inquiry teaching method has been found to be most suitable for the teaching of science, technical and engineering oriented courses by different scholars than the traditional teaching method (Nwagbo, 2001; Eick and Reed, 2002; Ibe and Nwosu, 2003; Alvarado and Herr, 2003; Glenda, Hebrank, Ybara and Kenk, 2005; Schwarz and Gwekwerere, 2006; Adeoye and Raimi, 2006; Prince and Felder, 2007). Owodunni \&Ogundola (2013)

There exist different techniques of the inquiry teaching, the differences between these techniques rest upon the mode of administration of the teaching method. Colburn (2000) opined that the differences among the techniques lie in the level of involvement of the teachers. These techniques include confirmation, structured, guided and open inquiry techniques. In confirmation inquiry, people are provided with the question and procedure (method) where the results are known in advance, and confirmation of the results is the object of the inquiry. Confirmation inquiry is useful to reinforce a previously learned idea. This inquiry technique is best in the elementary school level. In structured inquiry, people are provided with the question and procedure (method), however the task is to generate an explanation that is supported by the evidence collected in the procedure while in guided inquiry, people are provided with only the research question, and the task is to design the procedure (method) and to test the question and the resulting explanations. This kind of inquiry is more open than a structured inquiry. Lastly, in open inquiry, people form questions, design procedures for carrying out an inquiry, and communicate their results. McGraw Hill (2007) explained that the role of the teacher is to furnish the materials to be investigated to students. Majority of authors are united as to the complex nature of the open inquiry technique thereby making it unsuitable for use at the secondary school level (Denise, 1999; Adeyemi, 2000).

Some key elements of the inquiry technique that enhance effective teaching/learning process in an inquiry class include concept presentation. This is the explanation of a concept or principle underlying a given problem to be solved by teachers to students. (Ashton; 1988). Another inquiry tool is wait time usage. This is waiting a few seconds after asking questions from students, thereby giving them time to think before answering such question. Another element is the bringing of authentic and real life experience by teachers to classroom learning activities. This also provides real situation and contextualized knowledge about new information the students are learning. The use of scaffolding tools such as interactive journals and question prompts are elements that also promote inquiry teaching (Griffith \& Frieden, 2000; Kinchin \& Hay, 2000). Furthermore, collaborative learning in which students explore their understanding and misunderstanding together helps them to think about what they already know, what they need to know and how they would present and defend their own ideas in reaction to an instructional situation (William 2004). All these elements are necessary tools that will assist the teacher in the teaching of the skill requirements of modern auto mechanic.

Auto mechanic, also known as Car Mechanic, motor mechanic or Light Vehicle Mechanic is one of the trade courses offered in technical colleges in Nigeria. Auto mechanics are involved with the servicing, maintenance and repair of cars and light vehicles. The work is wide ranging and includes routine servicing in accordance with manufacturers' recommended procedures. The goal of auto mechanic, according to the National Board for Technical Education NBTE (2000) is to produce skilled craftsmen with good knowledge of the working principles of motor vehicles, the techniques and safety practices involve in its maintenance. Auto Mechanic programme in technical colleges are offered at levels leading to the award of National Technical Certificate (NTC) and Advanced National Technical Certificate (ANTC) for craftsmen and master craftsmen respectively (Federal Government of Nigeria, 2001)

In order to achieve the objective of effective training of competent auto mechanics, government at both the federal and state levels expended huge amount of money on the procurement of equipment for use in the 
technical colleges. In the same vein, such effort like curriculum review, policy shift, re-training, and production of technical college teachers by the government to ensure qualitative education at the technical colleges and bring about high quality products both in academics and for employment have not yielded much dividend. There have been persistent reports of high rate of failure among graduates of the Technical Colleges (FGN, 2001). Also, FGN (2006) in her reports on technical colleges revealed that students in technical colleges are always put-off or not been interested in vocational education because of the un-motivating and un-challenging methods and approach used by their teachers. Auto mechanic is an integral part of vocational and technical education, in order to facilitate teaching and learning, interest of the students; most especially as it affect gender is a relevant factor.

Gender differences in scientific interest depend to a large degree on the domains. There are well documented evidences that female turn away from such science courses like physics and chemistry than male students during schooling (Haeussler \& Hoffmann, 2000; Jones, Howe, \& Rua, 2000; Labudde, Herzog, Neuenschwander, Enrico, \& Gerber, 2000). Although recent studies have also indicated that the differences between girls and boys in the area of performance and that of interest in the sciences are now only very minimal (Martin et al., 2008; Organisation for Economic Co-operation and Development (OECD), 2009) Thus the inter play of gender in the interest of auto mechanic students when exposed to inquiry techniques is also worthy of investigating.

\section{Research Questions}

The following research questions were possed to guide this study:

1. What is the effect of structured and guided inquiry techniques on students' interest in studying motor vehicle mechanic work?

2. What is the effect of Gender on the interest of students (male and female) when taught motor vehicle mechanic work with the structured and guided inquiry techniques?

\section{Hypotheses}

The following null hypotheses were formulated to guide the study and will be tested at .05 level of significance: $\mathrm{HO}_{1}$ There will be no significant difference between the effect of treatments (structured and guided inquiry techniques) on students mean interest scores in MVMW interest inventory.

$\mathrm{HO}_{2}$ : There will be no significant difference between the effect of gender (male and female) on students mean interest scores in MVMW interest inventory.

$\mathrm{HO}_{3}$ : There will be no significant interaction effect of treatments given to students taught with inquiry techniques and their gender with respect to their mean scores on the interest inventory

\section{Methodology}

A quasi-experimental design with a pre-test and post- non-equivalent comparison group design was adopted. This design was considered suitable to conduct this study because intact classes (non-randomized groups) were assigned to the two different inquiry techniques as there was no plan to disrupt the schools' calendar.

The study was carried out in Ekiti State, Nigeria. The sample size for this study was all the 195 year II auto Mechanic students in the four technical colleges offering Auto Mechanic in Ekiti state. These comprised 160 male and 35 female students. The reason for choosing year II classes is that the students have undergone the curriculum of the trade in their year I and they could respond to the test items. Secondly, the major practical topics in motor vehicle mechanic work curriculum are in the second year The simple random sampling technique was adopted for randomly assigning the four colleges that offers motor vehicle mechanic work to both experimental groups (structured and guided) in the study. The four technical colleges offering MVMW and their corresponding student population are Government Technical College (GTC), Ado-Ekiti (53); Government Technical College (GTC), Ijero-Ekiti (41); Government Technical College (GTC), Ikole Ekiti (39); Federal Science and Technical College(FSTC), Usi Ekiti (62). Thus 94 of the subjects were assigned to guided technique (GTC Ado Ekiti and GTC ijero Ekiti) while 101 subjects were assigned to structured technique (GTC Ikole Ekiti and FSTC Usi Ekiti).

\section{Instrument for Data Collection}

The instrument used for data collection in this study was the Auto Mechanic Interest Inventory (AMII). The Auto Mechanic Interest Inventory (AMII) was developed by the researcher for the purpose of testing students' interest in motor vehicle mechanic work. The face and content validities were determined by experts in Auto Mechanic trade, test and measurement and language education. 
The experts were specifically requested to examine the AMII items with respect to the extent to which the statements in the AMII assess interest in the units of study. The suitability of the language used in the AMII with respect to the students' level of study and the extent of relationship between the AMII items and the student experiences in units of study. Following the face and content validation, the items were reviewed based on their comments, and thirty statements made up of 15 positive and 15 negative items were finally chosen to constitute the AMII. Thus Section A of the questionnaire contains items pertaining to the respondents' Bio data while section B contains the list of the thirty items based on five-point Likert scale of Strongly Agree (SA), Agree (A), Undecided (UD), Disagree (D) and Strongly Disagree (SD). Students are to respond to the items according to the level of agreement with each of them

The structured and guided inquiry (SI and GI) technique lesson plans were also developed by the researcher for the use of teaching the two experimental groups. Each of the lesson plans has the following inquiry elements built into it these include scaffolding tool usage, collaborative learning, wait-time usage, concept explanation and authentic and real life experience. Each SI and GI lesson plan indicated among others, the lesson topic, specific objectives, entry behaviour, instructional materials and the instructional procedure. The instructional procedure showed details of the steps, content development, students` and teachers`activities. The lesson plans were also validated by three experts in the department of vocational teacher education in the Faculty of Education, University of Nigeria, Nsukka. The experts were specifically requested to examine the extent to which the lesson plans conform to the theoretical basis of inquiry teaching method. Also, two motor vehicle mechanic work teachers took part in the validation of the lesson plans. The teachers were specifically requested to examine the lesson plans with respect to the extent to which:

1. The lessons covered the units of study

2. The lesson objectives were clearly stated

3. The objectives were appropriate for the students' level of study

4. Appropriate instructional materials were specified.

5. The evaluation questions were intimately related to the contents and lesson objectives.

The comments of both the experts and teachers were later used in rewriting the lesson plans.

Cronbach Alpha was used to determine the internal consistency of the Auto Mechanic Interest Inventory items. The AMII instrument was administered on 30 year II Auto mechanic trade students in Government technical college Osogbo, an area which was not part of the study area. The reliability coefficient computed for the Auto Mechanic Interest Inventory was found to be 0.85 . This formula was considered appropriate due to the fact that composite scores of the students on the instrument were required and also that the formula is applicable to items that are not dichotomously scored such as the AMII

\section{Experimental Condition}

Experimental Bias: The following conditions were laid down to minimize experimental bias: (a) the same lesson topic was taught to both experimental groups: (b) the same achievement test was given to both groups at the same time in order to avoid experimental bias :(c) the students had no pre knowledge of their involvement in the experiment: (d) the researcher was not directly involved in the test administration.

Teacher Variability: All lesson plans used for the study was prepared by the researcher in order to control invalidity that could be coursed by teacher variability.

Training of Teachers: A two -week intensive training was organized for the participating teacher by the researcher on the use of the structured and guided inquiry instructional techniques and their lesson plans

\section{Experimental Procedure}

The study was conducted in three phases, as described below:

The first phase was the pre-test stage. It was the phase in which the AMCAT was administered on the subjects in the two experimental groups. This phase of the study was done in the first week of the experiment. This exercise provided baseline data on cognitive achievement

The second phase which is the experimental or test phase featured the two experimental groups that were taught with the developed inquiry technique lesson plans. Auto mechanic teachers in each of the participating schools used the lesson plans to teach their own group. During the treatment, students were divided into groups of three and four. The workshop activities was organized in such a way that each of the groups was provided with a vehicle, clutch assembly, brake component and gear box assemblies (depending on the topic being treated), complete tool box, brush and petrol. Each of the two sets of lesson plan used for the study incorporated at least one inquiry teaching technique i.e. structured or guided inquiry technique.

The experimental group taught with the use of the structured inquiry technique was provided with probing questions or problems alongside complete step by step process or procedures that students followed in 
order to find or arrive at solutions to the problems. On the other hand, the experimental group taught with the guided inquiry teaching technique was not provided with complete procedural steps (as in the structured inquiry technique) for solving the problems. Rather, the teacher provided the problems to be solved and the explanation of the principle of operation to the students in addition to the provision of the practical materials needed to arrive at solutions. Students were expected to figure out the procedures or steps needed to solve the problems posed. Teachers were also at hand to attend to students' needs where necessary.

Each experimental group was taught for 10 weeks. Practical classes are always carried out once a week in all the schools used for the study. To this therefore, each of the experimental groups were taught for a total of ten periods. The third phase was the post-test phase. The phase also lasted for one week; the AMCAT (B) was administered as post-test. This exercise provided post intervention data on the cognitive achievement after the treatments. The data obtained from the students' scores were analyzed using mean for answering research questions and analysis of covariance (ANCOVA) to test the hypotheses of no significant difference

\section{Result}

The results of data analysed in this study are as follows

\section{Research Question 1}

What is the effect of structured and guided inquiry techniques on students' interest in studying motor vehicle mechanic work?

To answer the research question 3, the pre-test and post-test mean values were determined in respect of guided and structured inquiry techniques. The results are presented in table 3

Table 1 - Mean of Interest Inventory Scores of MVMW students taught with guided and structured Inquiry Techniques

\begin{tabular}{|c|c|c|c|c|}
\hline \multirow[t]{3}{*}{ Test } & \multicolumn{4}{|c|}{ Inquiry Techniques } \\
\hline & \multicolumn{2}{|c|}{ Guided Inquiry } & \multicolumn{2}{|c|}{ Structured Inquiry } \\
\hline & $\mathbf{n}$ & Mean & $\mathbf{n}$ & Mean \\
\hline $\begin{array}{l}\text { Pre-test } \\
\text { Post-test } \\
\text { Mean gain score }\end{array}$ & $\begin{array}{l}94 \\
94\end{array}$ & $\begin{array}{c}97.98 \\
136.53 \\
\mathbf{3 8 . 5 5}\end{array}$ & $\begin{array}{l}101 \\
101\end{array}$ & $\begin{array}{c}99.21 \\
136.34 \\
\mathbf{3 7 . 1 3}\end{array}$ \\
\hline
\end{tabular}

Table 1 shows that the treatment group taught motor vehicle mechanics work with guided inquiry technique had a mean interest score of 97.98 in the pretest and a mean interest score of 136.53 in the posttest making a posttest mean gain in the treatment group taught with guided inquiry to be 38.55 . The treatment group taught motor vehicle mechanics work with structured inquiry technique had a mean interest score of 99.21 in the pretest and a posttest mean of 136.34 with a posttest mean gain of 37.13 . With these results, both guided inquiry technique and structured inquiry technique are effective in stimulating students' interest in motor vehicle mechanics work but the effect of guided inquiry technique on students' interest in motor vehicle mechanics work is higher than the effect of structured inquiry technique.

\section{Research Question 2}

What is the effect of Gender on the interest of students (male and female) taught motor vehicle mechanic work with inquiry techniques?

To answer the research question 2, the pre-test and post-test mean values of male and female st udents were determined in respect of guided and structured inquiry techniques. The results are presented in table 2

Table 2 - Mean of Interest Inventory scores of MVMW students taught with Inquiry Techniques

\begin{tabular}{|c|c|c|c|c|c|c|c|c|}
\hline \multirow[b]{3}{*}{ Gender } & \multicolumn{8}{|c|}{ Inquiry Techniques } \\
\hline & \multicolumn{4}{|c|}{ Guided Technique } & \multicolumn{4}{|c|}{ Structured Technique } \\
\hline & $\mathrm{n}$ & Pretest & Posttest & $\begin{array}{c}\text { Mean } \\
\text { Gain } \\
\bar{X}\end{array}$ & $\mathrm{n}$ & Pretest & Posttest & $\begin{array}{c}\text { Mean } \\
\text { Gain } \\
\bar{X}\end{array}$ \\
\hline Male & 74 & 98.28 & 136.86 & 38.58 & 86 & 99.04 & 136.48 & 37.44 \\
\hline Female & 20 & 96.90 & 135.30 & 38.40 & 15 & 100.20 & 135.53 & 35.33 \\
\hline
\end{tabular}

The data presented in Table 2 shows that male students taught motor vehicle mechanic work with guided inquiry technique had a mean score of 98.28 in the pretest and a mean score of 136.86 in the posttest making a posttest mean gain in the male students taught with guided inquiry technique to be 38.58 . Meanwhile, female students taught motor vehicle mechanic work with guided inquiry technique had a mean score of 96.90 in the pretest and a posttest mean of 135.30 with a posttest mean gain of 38.40 Also, male students taught with the structured inquiry technique had a mean score of 99.04 in the pretest and a mean score of 136.48 in the 
posttest making a posttest mean gain in the male students taught with structured inquiry technique to be 37.44 Meanwhile, female students taught motor vehicle mechanic work with structured inquiry technique had a mean score of 100.20 in the pretest and a posttest mean of 135.53 with a posttest mean gain of 35.33 . With these results male students taught motor vehicle mechanic work with guided inquiry techniques had higher mean scores than female students in the Auto Mechanic Interest Inventory (AMII). Thus, there is an effect attributable to gender on the interest of students taught motor vehicle mechanic work with inquiry teaching techniques.

\section{Hypotheses}

$\mathrm{HO}_{1}$ : There will be no significant difference between the effect of treatments (structured and guided inquiry techniques) on students mean interest scores in MVMW interest inventory

$\mathrm{HO}_{2}$ : There will be no significant difference between the effect of gender (male and female) on students mean interest scores in MVMW interest inventory

$\mathrm{HO}_{3}$ : There will be no significant interaction effect of treatments given to students taught with inquiry techniques and their gender with respect to their mean scores on the interest inventory

Table 3 - Summary of Analysis of Covariance (ANCOVA) for Test of Significance of Three Effects: Treatments Gender and Interaction of Treatment and Gender on Students' Interest in MVMW

\begin{tabular}{|c|c|c|c|c|c|}
\hline Source of Variation & $\begin{array}{c}\text { Sum of } \\
\text { Squares }\end{array}$ & df & Mean Square & $\mathbf{F}$ & Sig of F \\
\hline Covariates & 8.83 & 1 & 8.83 & 1.28 & .26 \\
\hline Pre-test & 8.83 & 1 & 8.83 & 1.28 & .26 \\
\hline Effects & 44.17 & 2 & 22.08 & 3.20 & .04 \\
\hline Treatment & .50 & 1 & .50 & .07 & .79 \\
\hline Gender & 44.14 & 1 & 44.14 & 6.40 & .01 \\
\hline 2-way Interactions & 2.14 & 1 & 2.14 & .31 & .58 \\
\hline Treatment*Gender & 2.14 & 1 & 2.14 & .31 & .58 \\
\hline Explained & 60.61 & 4 & 15.15 & 2.20 & .07 \\
\hline Residual & 1311.21 & 190 & 6.90 & & \\
\hline TOTAL & 1371.82 & 194 & 7.07 & & \\
\hline
\end{tabular}

\section{*Significant at sig of $\mathbf{F}<.05$}

Table 3 shows F-calculated for three effects: treatment, gender and interaction of treatment and gender on students' interest in motor vehicle mechanics work. The F-calculated value for treatment is .07 with a significance of $\mathrm{F}$ at .79 which is greater than .05 . Hence, the null hypothesis of no significant difference between the effect of treatments (structured and guided techniques) on students' interest in motor vehicle mechanics work is upheld at .05 level of significance. The F-calculated for gender stood at 6.40 with a significance of $\mathrm{F}$ at .01 which is less than .05 . The null-hypothesis is therefore rejected at .05 level of significance. With this result there is a significant effect of gender (male and female) on students' interest in motor vehicle mechanics work. The interaction effect of treatment and gender has F-calculated value of .31 with significance of F of .58 which is greater than .05 . This result means that there is no significant interaction effect of treatments given to students taught motor vehicle mechanics work with inquiry techniques and their gender with respect to their mean scores in the Interest Inventory.

\section{Findings of the Study}

The following findings emerged from the study based on the data collected and analyzed and hypotheses tested. 8. There was no significant difference between the effect of treatments (structured and guided techniques) on students' interest in motor vehicle mechanics work.

9. There was a significant effect of gender (male and female) on students' interest in motor vehicle mechanics work.

10. There was no significant interaction effect of treatments given to students taught motor vehicle mechanics work with inquiry techniques and their gender with respect to their mean scores in the Interest Inventory.

\section{Discussion of findings}

The data presented in Table 1 provided answer to research question one. Finding revealed that both structured inquiry and guided inquiry techniques are effective in improving students' interest in motor vehicle mechanic work but the effect of Guided inquiry technique on students' interest in motor vehicle mechanic work is higher than the effect of structured inquiry techniques. This finding indicates that Guided inquiry technique is more effective in stimulating students' interest in motor vehicle mechanic work than the structured technique. However, the Analysis of covariance of the treatments effects on interest presented in Table 3 showed that there was no significant difference between the effects of treatments (Structured inquiry and guided techniques) on students' interest in motor vehicle mechanic work. Thus, the difference between the Guided inquiry technique 
and structured inquiry technique on students' interest in motor vehicle mechanic work was not found significant. The lack of differences between the groups may be because in both research groups the inquiry process involves practical work. Lazarowitz (2007) assumed that students' practical, outdoor or field work helped them develop responsibility and a sense of caring for the environment. This finding is in agreement with previous research that reports outdoor learning is popular with students (Orion, Hofstein, Tamir and Giddings, 1997), raises curiosity (McGlashan, Gasser, Dow, Hartney, and Rogers, 2007), and engenders fun (Orion et. al, 1997). Although there was no overall significant difference between the groups, guided inquiry students planned their project, and they were exposed to change and expressed anticipation (Yen and Huang, 2006; Zion, 2009), whereas structured inquiry students were led by the teacher, thus they were less exposed to change, more passive than their guided inquiry peers, and did not express feelings of anticipation. Without anticipation, there is often no disappointment and no surprise (Castelfranchi and Lorini, 2003).

Furthermore, another salient finding from this study is that it was found that male students taught motor vehicle mechanic work with Inquiry techniques had higher mean scores than female students in the Motor mechanic Interest Inventory, revealing that there is an effect attributable to gender on the interest of students taught motor vehicle mechanic work with Inquiry techniques. However, analysis of covariance of test of significant difference between the effect of gender on students' interest in motor vehicle mechanic work as presented in Table 3 showed that there was no significant difference between the effect of gender (male and female) on students' interest in motor vehicle mechanic work. This means that the observed difference in the mean interest scores of male and female students was not statistically significant. Interestingly, providing of opportunities to interact with course material through the use of appropriate real live vehicle components, tools and equipment cooperatively tends to change the course from a competitive endeavour to one that is more student-centred, and focused on the construction of knowledge in the students (Brewer, 2003). Hence, one means of constructing knowledge is to create meaning by doing. Creating support for knowledge construction within the students is a critical component to the success of developing self-motivated, intellectually stimulated learners (Osberg, et al., 1997). The obvious implication of the use of appropriate real live vehicle components, tools and equipment therefore, is to facilitate students' interaction with the learning environment. This will help to sustain students' interest which increases the strength of ego-involvement of the learners and which does not allow the learners to be distracted by trivial extraneous events in the perceptual environment.

Analysis of covariance was used to test hypothesis 3 , Table 3 , at the calculated F-value (.31), significance of F (.58) and confidence level of .05, the interaction effect of treatment and gender was not found to be significant. This implies that the effectiveness of Inquiry techniques on students' interest in motor vehicle mechanic work is independent of gender.

\section{Conclusion and Recommendation}

The influence of technological advancement in automobiles has rendered traditional skills inadequate for work in the automobile industry. This advancement in technology has created the need for new and often sophisticated skills. Obviously, the automobile industry needs the service of Auto mechanics that can adapt to the changes in technology in the industry. Greater stress need therefore be placed on providing students with broad learning and problem-solving skills in order to prepare them for a wide range of challenges posed by technological advancement which has occasioned the need to seek for alternative instructional method such as guided inquiry to teach the modern work place skills requirements of the industry. Moreover, it has been discovered that the persistent poor academic achievement and low interest of students in Auto Mechanic and other trade curses in technical colleges is as a result of the inappropriate teaching methods adopted by teachers (Aina, 2000). The need to find the appropriate teaching technique to assist Technical college students to learn Auto mechanic and naturally increase students' interest, involvement and commitment in learning, is the focus of the study.

Based on the findings of this study, the following recommendations are made:

1. Technical teachers of Auto Mechanic should adopt the use of Guided inquiry technique to the teaching of Auto Mechanic. in such a way that students are allowed ample opportunity to interact freely with one another in the Guided inquiry space so as to increase students interest in auto mechanic and invariably improve both their psychomotor and cognitive achievement

2. Workshops, seminars and conferences should be organized by Ministry of Education, NABTEB and NBTE to enlighten technical teachers and improve their knowledge and skills on the use of Guided inquiry techniques for improving students' interest in vocational education generally and auto mechanic in particular.

\section{References}

[1]. Adeyemi M. A. (2000) The strategy of inquiry in the teaching and learning of science: Lagos, Goldprints publishers

[2]. Adeoye I. F. and Raimi, S. M. (2006).Effects of Inquiry and Expository Instructional Strategies on Students Achievement in integrated Science Concepts Akoka Journal of Education, Vol.3 No. (1). 
[3]. Aina,, O. (2000). Nigeria technical and vocational education in the near future. In Federal Ministry of Education (2001), The National Master-plan for Technical and Vocational Development in Nigeria in the $21^{\text {st }}$ Century with the Blue Print for the Decade 2010. Abuja, FME.

[4]. Alvarado, A. E., \& Herr, P.R. (2003). Inquiry-based learning using everyday objects. Hands on instructional strategies that promote active learning in grades 3-8. Corwin Press Inc.: Thousand Oaks, California

[5]. Agboola, O. S. and Oloyede, E. O. (2007) Effects of project, inquiry and lecture-demonstration teaching methods on senior secondary students achievement in separation of mixtures practical test. Journal of Educational Research and Review .vol . 2(6) 124-132.

[6]. Ashton P (1988). Teaching Higher-Order Thinking and Content : An Essential Ingredient in Teacher preparation. Gainesville Fla. University of Florida

[7]. Castelfranchi, C. \& Lorini, E. (2003). Cognitive Anatomy and Functions of Expectations. In Proceedings of IJCAI'03 Workshop on Cognitive Modeling of Agents and Multi-Agent Interactions, Acapulco, Mexico, August 9-11

[8]. Chukwu, A. (2002). Promoting students' interest in mathematics using local games. International Journals of Arts and Technology Education. 2(1), 54-56

[9]. Colburn, A. (2000). An Inquiry Primer. Retrieved April 20,2009 from www.experientiallearning.ucdavis.edu/module2/el2-60-primer.pdf

[10]. Davis, E. (1996) Metacognitive Scaffolding to foster scientific explanations, paper presented at the annual meeting of the American Educational Research Association, Retrieved May 10, 2007 from http://www.liebertonline.com/doi/pdfplus/10.1089/cpb2006.9.174

[11]. Denis J. (1999). The inclusive classroom : Mathematics and Science instruction for students with learning disabilities. Retrieved 11 November 2009 from Weber U. Washington. Edu/doit.

[12]. Eick, C.J. \& Reed, C.J. (2002). What Makes an Inquiry Oriented Science Teacher? The Influence of Learning Histories on Student Teacher Role Identity and Practice. Science Teacher Education, 86, pp 401-416.

[13]. Federal Government of Nigeria (2001) Technical and Vocational Education Development in Nigeria: The way forward, Report of the Advisory panel of inquiry on TVE in Nigeria, Abuja: Federal Government Press

[14]. Federal Government of Nigeria (2006).A report from Federal Ministry of Education on technical colleges. Lagos: NERDC Press

[15]. Glenda T. K., Hebrank M., Ybarra G. A. and. Klenk P. A (2005). Teaching K-12 Engineering usingInquiry-Based Instruction. Proceedings of the 2005 American Society of Engineering Education Annual Conference \& Exposition. Retrieved on $21^{\text {st }} \mathrm{July} 2008$ from ASEE 2005-1916_Final_Duke_TeachingK-12Engr.pdf

[16]. Haeussler, P., Hoffmann, L. (2000). A curricular frame for physics education: Development, comparison with students' interests, and impact on students' achievement and self concept Science Education, 84, 689-705.

[17]. Hemelo, A. and Ferrari, M. (1997) Inquiry based-approach in Education: Retrieved November, 15 2008 from http//:www.csuasedu/turner/papers/harthticc2005doc.

[18]. Hidi, S., \& Renninger, A. (2006). The four-phase model of interest development. Educational Psychologist, 41, 111-127.

[19]. Jones, M. G., Howe, A., \& Rua, M. J. (2000). Gender differences in students' experiences, interests, and attitudes toward science and scientists. Science Education, 84, 180-192.

[20]. Kinchin, Y. and Hay R (2000) A serious application of web tool in inquiry. Retrieved January, 20th 2009 from http://www.wikisym.org/ws2008/proceedings/p.40.pdf

[21]. Krapp, A. (2002). An educational-psychological theory of interest and its relation to self determination theory. In E. Deci \& R. Ryan (Eds.), The handbook of self-determination research (pp. 405-427). Rochester, NY: University of Rochester Press

[22]. Labudde, P., Herzog, W., Neuenschwander, M. P., Enrico, V., \& Gerber, C. (2000). Girls and physics: Teaching and learning strategies tested by classroom interventions in grade 11. International Journal of Science Education, 20, 143-157.

[23]. Martin, M. O., Mullis, I. V. S., \& Foy, P. (with Olson, J. F., Erberber, E., Preuschoff, C., \& Galia, J.). (2008). TIMSS 2007 international mathematics report: Findings from IEA's trends in international mathematics and science study at the fourth and eighth grade. Chestnut Hill, MA: TIMSS \& PIRLS International Study Center, Boston College.

[24]. McGraw-Hill (2007). What is inquiry in Science. Retrlieved in $5^{\text {th }}$ October, 2007 from http://books.google.com/books? $h l=e n \& l r=\& i d=y 3 A H b 4 d J y 30 C \& o i=f n d \& p g=P A 379 \& d q=M c G r a w-$ Hill\%27+What+is+inquiry+in+science html

[25]. Moon, J. G. (1999). Reflective teaching: becoming an inquiring educator. New York: Macmillan publishing company

[26]. National Board for Technical Education (NBTE 2000).National Technical certificate and Advanced National Technical certificate curriculum and module specifications for motor vehicle mechanic work. Kaduna: NBTE.

[27]. Ngwoke, D. U. (2004). School Learning theories and applications. Enugu: Magnet Business Enterprise

[28]. Ogwo, B. A. \& Oranu, R. N. (2006). Methodology in informal and non formal technical/vocational education. Nsukka: University if Nigeria press Ltd

[29]. Organisation for Economic Co-operation and Development. (2009). Equally prepared for life? How 15-year-old boys and girls perform in school. Paris: OECD

[30]. Orion, N., Hofstein, A., Tamir, P. \& Giddings, G.J. (1997). Development and validation of an instrument for assessing the learning environment of outdoor science activities. Science Education, 81(2): p.161-171

[31]. Owodunni Ayanda Samuel and Ogundola Ilesanmi Peter (2013) Gender Differences in the Achievement and Retention of Nigeria Students Exposed to Concept in Electronic Works Trade through Reflective Inquiry Instructional Technique British Journal of Education, Society \& Behavioural Science 3(4): 589-599

[32]. Osberg, K. M., Winn, W., Rose, H., Hollander, A., Hoffman, H., \& char, P., (1997). The effect of having grade seven students construct virtual environments on their comprehension of science. Retrieved September 18, 2007, from http://www.hilt.washinton.edu/publications/r97-19

[33]. Osuafor, A. M. (2001). Effects of field Trip and Role Playing on Pupils Achievement and Interest in Environmental Concepts in Primary Science. Unpublished Ph.D Thesis, University of Nigeria, Nsukka.

[34]. Prenzel, M. (1992). Selective persistence of interest. In K. A. Renninger, S. Hidi, \& A. Krapp(Eds.), The role of interest in learning and development (pp. 71-98). Hillsdale, N Erlbaum

[35]. Prince, M., \& Felder, R. (2007). The many faces of inductive teaching and learning. Journal of College Science Teaching, 36(5), 14-21

[36]. Schiefele, U., Krapp, A., \& Winteler, A. (1992). Interest as a predictor of academic achievement: A meta-analysis of research. In K. A. Renninger, S. Hidi, \& A. Krapp (Eds.), The role of interest in learning and development (pp. 183-212). Hillsdale, NJ: Erlbaum.

[37]. Schwarz C.V. and Gwekwerere Y.N.(2006). Using a Guided Inquiry and Modeling Instructional Framework (EIMA) to Support Pre-service K-8 Science Teaching Retrieved August 20, 2009, from http://www.ksg.harvard/pepg/pdf/events/munich/PEPG-04-24strom.pdf

[38]. Silvia, P. J. (2006). Exploring the psychology of interest. New York: Oxford University Press.

[39]. William G. H. (2004) A Balanced Approach to Science Inquiry Teaching Journal of Science \& Technology Education Volume 25, Part II, 201-217, retrieved on 20 September,2010from http://www.springerlink.com/content/u412728148166p60

[40]. Yen, B.S.\& Huang, F (2006) Comparative Study of Authentic Scientific Research Versus Guided Inquiry in Affecting Middle School Students' Abilities to Know and Do Genetics. Unpublished Ph.D Thesis, Austin State University 